Jurnal Ilmu Olahraga Volume I Nomor 1 Oktober 2018

Edi Purnomo, et.all.

Tersedia di: http://jurnal.untan.ac.id/index.php/jilo

\title{
EVALUASI PELAKSANAAN PERKULIAHAN PROGRAM STUDI PENDIDIKAN KEPELATIHAN OLAHRAGA
}

\author{
Edi purnomo, Urai Gustian, Isti Dwi Puspita Wati, Eka Supriatna, Y. Touvan juni samodra \\ Program studi Pendidikan Kepelatihan Olahraga, \\ Fakultas Keguruan dan Ilmu Pendidikan, Universitas Tanjungpura
}

\begin{abstract}
ABSTRAK
Penelitian ini bertujuan untuk mengevaluasi perkuliahan yang terjadi dan telah berlangsung pada program studi pendidikan kepelatihan olahraga. Penelitian dilakukan terhadap mahasiswa pendidikan kepalatihan olahraga angkatan 2014 dan 2015. Penelitian dilakukan pada akhir semester genap tahun ajaran 2015. Data diambil dengan menggunakan angket dengan 5 tingkat skala, kurang sekali, kurang, cukup, baik, baik sekali. Hasil penelitian menunjukkan bahwa perkuliahan yang telah berlangsung telah berjalan dengan baik. Dengan persentasi diatas $80 \%$.
\end{abstract}

Kata kunci: evaluasi perkuliahan

\section{TEACHING LEARNING EVALUATION IN SPORT COACHING DEPARTEMENT}

Edi purnomo, Urai Gustian, Isti Dwi Puspita Wati, Eka Supriatna, Y. Touvan juni samodra Sport Coaching Departmen Faculty of Teacher Training and Education Universitas Tanjungpura

\begin{abstract}
The aim this research to evaluate teaching learning process in sport coaching department. Research were in the of semester 2015. Data was collected by questionare with 5 scale, very goog, good, enough, less and more less. Result research study shown teaching learning happened was running good, with $80 \%$ above answer good for the questionares.
\end{abstract}

Key words: evaluation teaching learning. 
Jurnal Ilmu Olahraga Volume I Nomor 1 Oktober 2018

Edi Purnomo, et.all.

Tersedia di: http://jurnal.untan.ac.id/index.php/jilo

\section{A. PENDAHULUAN}

Pola proses pembelajaran dosen aktif dengan mahasiswa pasif ini efektifitasnya rendah, dan tidak dapat menumbuh kembangkan proses partisipasi aktif dalam pembelajaran. Keadaan ini terjadi sebagai akibat elemen-elemen terbentuknya proses partisipasi yang berupa, (i) dorongan untuk memperoleh harapan (effort), kemampuan mengikuti proses pembelajaran, dan (iii) peluang untuk mengungkapkan materi pembelajaran yang diperolehnya di dunia nyata/masyarakat tidak ada atau sangat terbatas.

Penelitian ini memberikan sumbangan data empiris untuk memperbaiki mutu pelaksanaan perkuliahan pada program studi yang ada pada jurusan Ilmu keolahragaan khususnya pada program studi Pendidikan Kepelatihan Olahraga. Sebagai kajian ilmiah pembahasan secara mendalam pokok penelitian, sebagaimana judul diatas, masih sangat terbatas. Penelitian ini merupakan dasar pertimbangan untuk meningkatkan kulaitas pembelajaran prodi pendidikan kepelatihan sebagai prodi yang akan menghadapi akreditasi. Penelitian ini juga diharapkan memberikan kontribusi dalam pengembangan pembangunan sistem dan kebijaksanaan akademik program studi, serta bahan refleksi bagi civitas akademika.

Penelitian ini merupakan sebagaian kecil upaya untuk bercermin terhadap kinerja dosen dilihat dari sisi persepsi mahasiswa. Tujuan akhirnya adalah untuk melakukan pengendalian mutu internal dan pada akhirnya merujuk pada permbikan dan keluaran dari proses pembelajaran memiliki kompetensi yang lebih tinggi sehingga akan meningkatkan daya saing alumni. Daya saing alumni ini merujuk pada persaingan lokal dan nasional prodi pendidikan kepelatihan olahraga. Kegiatan penelitian ini merupakan salah satau upaya menjalankan penjaminan mutu internal di program studi, melalui evaluasi secara berlaka.

Pelaksanaan perkuliahan yang baik merupakan komponen yang penting dalam penjaminan mutu proses akademik internal perguruan tinggi. Masalah yang muncul yang diteliti adalah apakah pelaksanaan perkuliahan oleh para dosen telah berjalan sesuai dengan standar pelaksanaan perkuliahan yang telah ditetapkan?

Dosen sebagai komponen yang sangat menentukan dalam implementasi strategi pembelajaran. Keberhasilan implementasi strategi pembelajaran akan tergantung pada kepiawaian dosen dalam menggunakan atau menerapkannya. Suatu proses pembelajaran dikatakan berhasil apabila mahasiswa dapat mencapai tujuan pembelajaran secara optimal sesuai visi dan misi yang telah ditetapkan serta dapat memenuhi kompetensi ynag dibutuhkan oleh stakeholder.

Penelitian ini akan memfokuskan pada pelaksanaan perkuliahan yang dilakukan oleh dosen program studi Pendidikan Kepelatihan Olahraga pada semester genap tahun akademik 2015/2016. Orientasi penelitian meliputi komponen-komponen:
a. Penguasaan dan wawasan terhadap materi perkuliahan
b. Penggunaan metode dan strategi dalam pelaksanaan perkuliahan,
c. Pemanfaatan media pembelajaran,
d. Penilaian hasil belajar, dan
e. Kemanfaatan yang diperoleh mahasiswa dalam perkuliahan.

\section{B. METODE PENELITIAN}

Penelitian ini dimaksudkan untuk: 1) mengetahui pelaksanaan penyelenggaraan 
pembelajaran pada program studi Pendidikan Kepelatihan Olahragadalam kaitannya dengan aspek penjaminan mutu akademiknya, dan 2) identifikasi pola pembelajaran yang dilakukan oleh para dosen dalam upaya meningkatkan mutu pembelajaran yang relevan dengan kompetensi yang diharapkan pada lulusan, dan 3) rekomendasi perbaikan menuju penguatan mutu akademik, khususnya dalam pelaksanaan perkuliahan.

Berdasarkan rumusan masalah penelitian dan maksud atau tujuan tersebut diatas, maka penelitian dilaksanakan dengan pola dan pendekatan penelitian deskriptif berbentuk survei.

Kegiatan penelitian ini telah dilakukan melalui empat tahapan, yaitu :

1. Tahap persiapan proposal; diskusi menelaah komponen yang akan diteliti sehingga data akan bermanfaaf bagi program studi untuk kepentingan peningkatan iklim akademik. Ditentukan juga angkatan yang akan diteliti, direncanakan karena baru ada dua angkatan maka akan dijadikan semua mahasiswa sebagai responden. Adapun mata kulian yang akan dijadikan obyek penelitian adalah semua mata kuliah yang diikuti pada semester ini.

2. Tahap penyusunan. Instumen yang dipergunakan adala instrumen yang telah dikembangkan dari penjaminan mutu fakultas. Sehingga instrument ini pernah dipergunakan pada penellitian sebelumnya.

3. Tahap survei; direncanakan penelitian dilaksanakan sebelum mahasiswa libur lebaran, sehingga memori terhadap proses perkuliahan masih nyata dan segar. Mahasiswa diberi pengertian pentingnya penelitian ini sebagai upaya untuk peningkatan mutu perkuliahan, sehingga pengisian angket pada akhirnya untuk kemajuan akademik bersaman.

4. Tahap penyajian data dan penarikan kesimpulan.

Sumber data adalah mahasiswa yang kuliah di prodi pendidikan kepelatihan olahraga dua angkatan. Direncanakan penelitian ini adalah penelitian populasi, sehingga semua mahasiswa diharapkan berpartiipasi dalan pengisian angket yang telah disusun oleh tim peneliti.

Teknik pengumpulan data dilakukan dengan tes persepsi menggunakan angket. Angket yang disebarkan ke mahasiswa berusaha untuk menggali secara ringkas proses perkuliahan yang akan segera berakhir. Pertanyaan pertanyaan tertutup yang diajukan akan lebih memudahkan dalam menjawab dan berpersepsi terhadap dosen yang mengajar. disediakan lembar uraian bebas jika mahasiswa berkeinginan untuk memberi masukan ke dosen atau prodi keterkaitan dengan angket yang diisi.

Analisis data dari angket yang dikembalikan mahasiswa akan dianalisis dengan menggunakan statistik deskriptif. Hasil dari analisis statistic kemudian dimaknai dengan melihat prosentasi persepsi mahasiswa terhadap perkuliahan yang berlangsung dan sebagai masukan kepada program studi dan dosen untuk proses pembelajaran lebih lanjut guna peningkatan mutu agar tarcapai visi misi program studi.

\section{HASIL PENELITIAN DAN PEMBAHASAN}

1. Deskripsi Hasil Penelitian

Penelitian dilaksanakan pada bulan Juli-Agustus 2016. Sampel penelitian seluruh mahasiswa kepelatihan olahraga angkatan pertama 2014 dan angkatan kedua 2015. Mahasiswa mengisi angket yang telah 
disusun untuk memberikan evaluasi terhadap pelaksanaan perkuliahan selama semester IV tahun ajaran 2015/2016 yang telah selesai dilaksanakan. Berdasarkan tabulasi data yang diperoleh dalam penelitian ini dikumpulkan pendapat mahasiswa terhadap 16 pertanyaan mengenai perkuliahan yang berkaitan diantaranya;

Berdasarkan pada angket diatas kemudian diberikan ke mahasiswa, hasil dari pendapat mahasiswa terhadap perkuliahan yang telah dilalui terhadap 9 mata kuliah untuk setiap angkatan hasilnya sebagai berikut.

\section{a) Mata kuliah atletik II}

Mata kuliah atletik II merupakan mata kuliah teori dan praktek di lapangan. Mata kuliah ini merupakan matakuliah wajib. Dari 16 angket rentang nilai 1 sampai 5 jika dipersentasekan jumlah jawaban yang memberi jawaban baik $48.25 \%$ dan baik sekali $37,15 \%$. Jika dipahami secara keseluruhan dapat dikatakan kualitas hasil evaluasi perkuliahan mata kuliah atletik ini adalah $80 \%$ dengan kualitas baik. Hal ini dapat dilihat lebih jelas dengan memperhatikan tabel sebagai berikut:

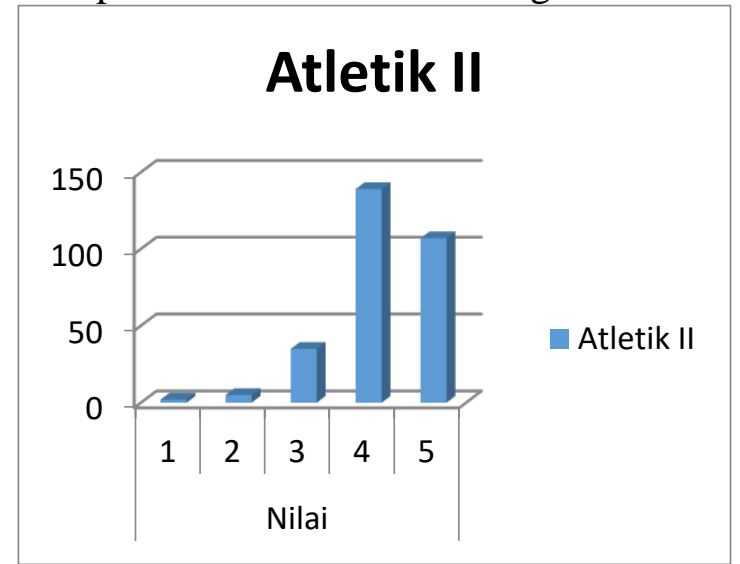

Grafik 1. Grafik hasil evaluasi perkuliahan atletik II

\section{b) Mata kuliah psikologi pendidikan}

Mata kuliah psikologi pendidikan merupakan mata kuliah teori. Mata kuliah ini merupakan matakuliah wajib. Dari 16 angket rentang nilai 1 sampai 5 jika dipersentasekan jumlah jawaban yang memberi jawaban baik $58 \%$ dan baik sekali 27\%. Jika dipahami secara keseluruhan dapat dikatakan kualitas hasil evaluasi perkuliahan mata kuliah atletik ini adalah $85 \%$ dengan kualitas baik. Hal ini dapat dilihat lebih jelas dengan memperhatikan tabel sebagai di atas.

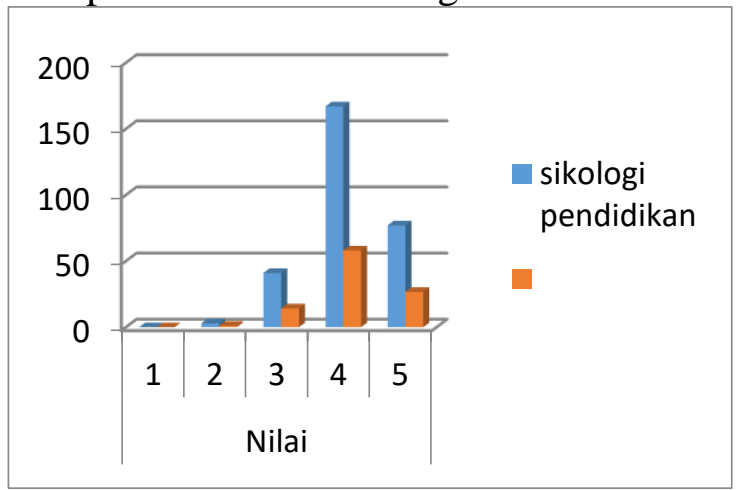

Grafik 2. Grafik hasil evaluasi perkuliahan psikologi pendidikan

\section{c) Mata kuliah Anatomi \\ Mata kuliah Anatomi merupakan} mata kuliah teori. Mata kuliah ini merupakan matakuliah wajib. Dari 16 angket rentang nilai 1 sampai 5 jika dipersentasekan jumlah jawaban yang memberi jawaban baik 58\% dan baik sekali $26 \%$. Jika dipahami secara keseluruhan dapat dikatakan kualitas hasil evaluasi perkuliahan mata kuliah atletik ini adalah $84 \%$ dengan kualitas baik. Hal ini dapat dilihat lebih jelas dengan memperhatikan tabel sebagai berikut: 


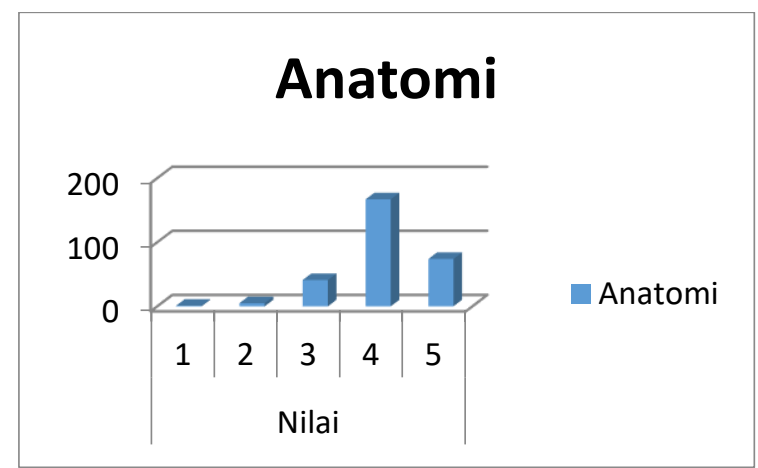

Grafik 3. Grafik hasil evaluasi perkuliahan Anatomi

\section{d) Mata kuliah Pencak Silat}

Mata kuliah Pencak Silat merupakan mata kuliah teori dan praktek di lapangan. Mata kuliah ini merupakan matakuliah wajib. Dari 16 angket rentang nilai 1 sampai 5 jika dipersentasekan jumlah jawaban yang memberi jawaban $56 \%$ dan baik sekali $36 \%$. Jika dipahami secara keseluruhan dapat dikatakan kualitas hasil evaluasi perkuliahan mata kuliah pencak silat ini adalah 92\% dengan kualitas baik. Hal ini dapat dilihat lebih jelas dengan memperhatikan tabel di atas.

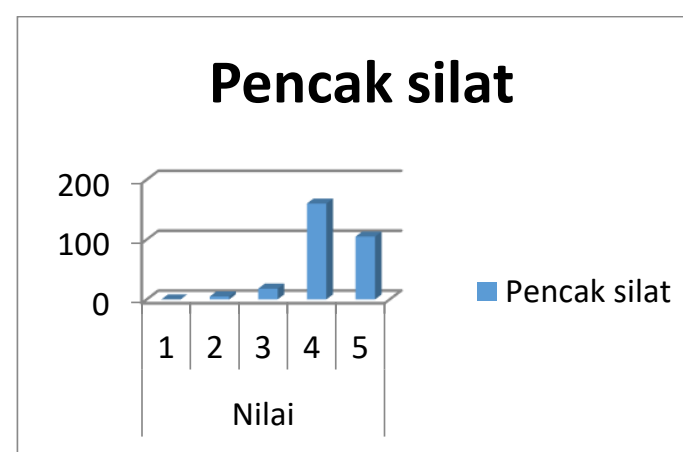

Grafik 4. Grafik hasil evaluasi perkuliahan pencak silat

e) Mata kuliah senam lantai

Mata kuliah senam lantai merupakan mata kuliah teori dan praktek di lapangan. Mata kuliah ini merupakan matakuliah wajib. Dari 16 angket rentang nilai 1 sampai 5 jika dipersentasekan jumlah jawaban yang memberi jawaban baik $67 \%$ dan baik sekali
30\%. Jika dipahami secara keseluruhan dapat dikatakan kualitas hasil evaluasi perkuliahan mata kuliah senam lantai ini adalah 97\% dengan kualitas baik. Hal ini dapat dilihat lebih jelas dengan memperhatikan tabel sebagai berikut:

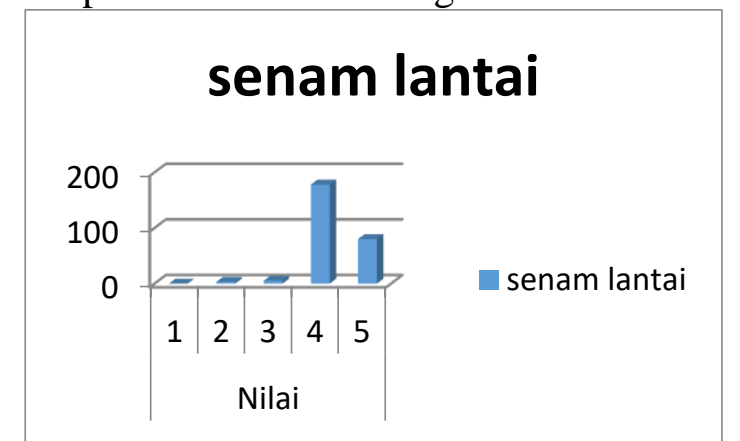

Grafik 5 Grafik hasil evaluasi perkuliahan senam lantai

f) Mata kuliah sepak bola

Mata kuliah sepak bola merupakan mata kuliah teori dan praktek di lapangan. Mata kuliah ini merupakan matakuliah wajib. Dari 16 angket rentang nilai 1 sampai 5 jika dipersentasekan jumlah jawaban yang memberi jawaban baik $58 \%$ dan baik sekali $10 \%$. Jika dipahami secara keseluruhan dapat dikatakan kualitas hasil evaluasi perkuliahan mata kuliah sepak bola ini adalah $68 \%$ dengan kualitas baik. Hal ini dapat dilihat lebih jelas dengan memperhatikan tabel di atas.

\section{sepak bola}

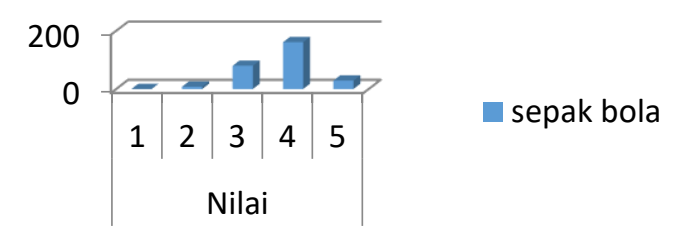

Grafik 6 Grafik hasil evaluasi perkuliahan sepak bola

g) Mata kuliah Pendidikan agama 
Jurnal Ilmu Olahraga Volume I Nomor 1 Oktober 2018

Edi Purnomo, et.all.

Tersedia di: http://jurnal.untan.ac.id/index.php/jilo

Mata kuliah Pendidikan agama merupakan mata kuliah teori. Mata kuliah ini merupakan matakuliah wajib. Dari 16 angket rentang nilai 1 sampai 5 jika dipersentasekan jumlah jawaban yang memberi jawaban baik $57 \%$ dan baik sekali 27\%. Jika dipahami secara keseluruhan dapat dikatakan kualitas hasil evaluasi perkuliahan mata kuliah agama ini adalah $84 \%$ dengan kualitas baik. Hal ini dapat dilihat lebih jelas dengan memperhatikan tabel sebagai berikut:

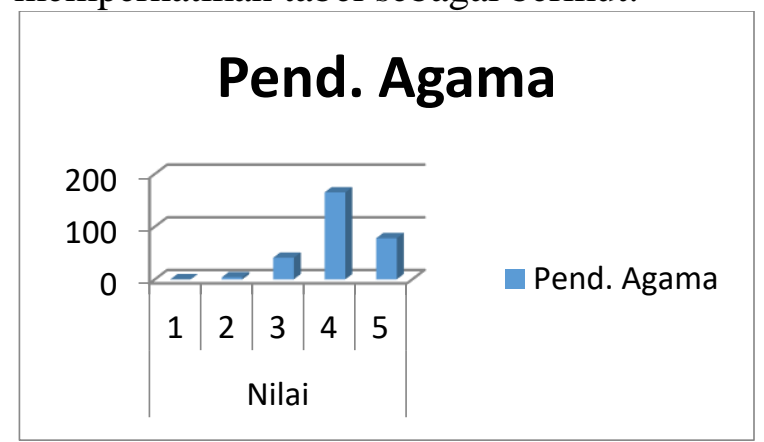

Grafik 7. Grafik hasil evaluasi perkuliahan Pendidikan agama

h) Mata kuliah Bahasa Inggris

Mata kuliah Bahasa Inggris merupakan mata kuliah teori. Mata kuliah ini merupakan matakuliah wajib. Dari 16 angket rentang nilai 1 sampai 5 jika dipersentasekan jumlah jawaban yang memberi jawaban baik $48 \%$ dan baik sekali 24\%. Jika dipahami secara keseluruhan dapat dikatakan kualitas hasil evaluasi perkuliahan mata kuliah Bahasa Inggris ini adalah $72 \%$ dengan kualitas baik. Hal ini dapat dilihat lebih jelas dengan memperhatikan tabel sebagai di atas.

\section{B Inggris}

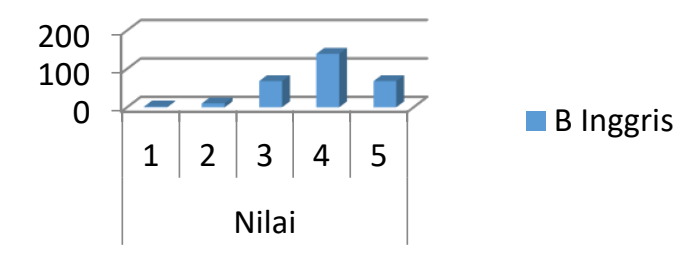

Grafik 8. Grafik hasil evaluasi perkuliahan Pendidikan agama dan Bahasa Inggris

i) Mata kuliah kecabangan spesialisasi

Mata kuliah kecabangan spesialisasi merupakan mata kuliah teori dan praktek di lapangan. Mata kuliah ini merupakan matakuliah wajib. Dari 16 angket rentang nilai 1 sampai 5 jika dipersentasekan jumlah jawaban yang memberi jawaban baik 50\% dan baik sekali 24\%. Jika dipahami secara keseluruhan dapat dikatakan kualitas hasil evaluasi perkuliahan mata kuliah kecabangan spesialisasi ini adalah 74\% dengan kualitas baik. Hal ini dapat dilihat lebih jelas dengan memperhatikan tabel sebagai berikut:

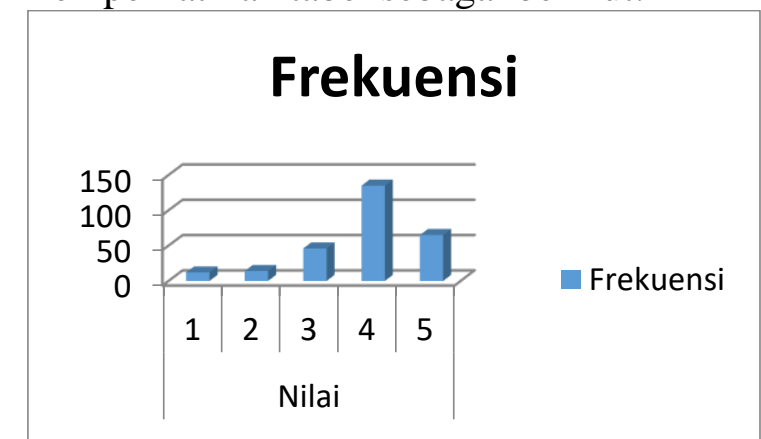

Grafik 9. Grafik hasil evaluasi perkuliahan kecabangan spesialisasi

\section{Mata kuliah matakuliah pada semester IV}

j) Mata kuliah sport massage

Mata kuliah Pencak Silat merupakan mata kuliah teori dan praktek di lapangan. Mata kuliah ini merupakan matakuliah wajib. Dari 16 angket rentang nilai 1 sampai 5 jika dipersentasekan jumlah jawaban yang memberi jawaban baik $65 \%$ dan baik sekali 26\%. Jika dipahami secara keseluruhan dapat dikatakan kualitas hasil evaluasi perkuliahan mata kuliah sport massage ini adalah 91\% dengan kualitas baik. Hal ini dapat dilihat lebih jelas dengan memperhatikan tabel sebagai berikut: 


\section{sport massage}

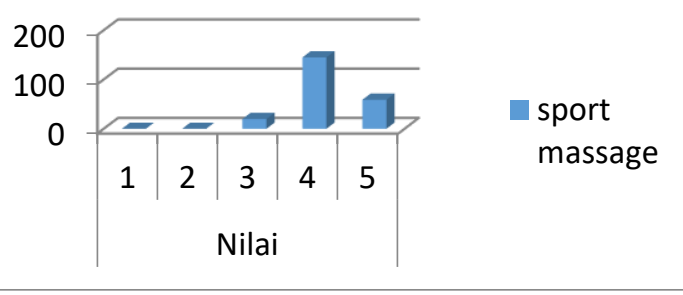

Grafik 10. Grafik hasil evaluasi perkuliahan sport massage

k) Mata kuliah spesialisasi cabang olahraga

Mata kuliah cabang olahraga merupakan mata kuliah teori dan praktek di lapangan. Mata kuliah ini merupakan matakuliah wajib. Dari 16 angket rentang nilai 1 sampai 5 jika dipersentasekan jumlah jawaban yang memberi jawaban baik $67 \%$ dan baik sekali $15 \%$. Jika dipahami secara keseluruhan dapat dikatakan kualitas hasil evaluasi perkuliahan mata kuliah spesialisasi cabang olahraga ini adalah $82 \%$ dengan kualitas baik. Hal ini dapat dilihat lebih jelas dengan memperhatikan tabel di atas.

\section{spesialis cabor}

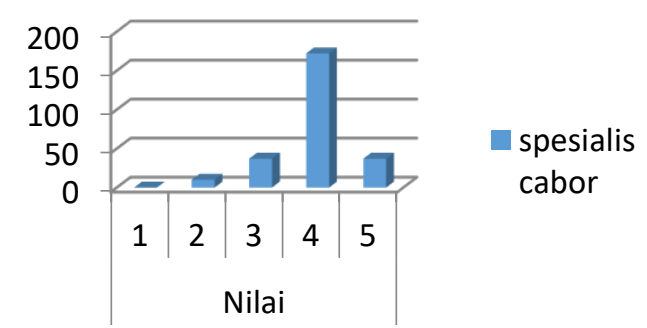

Grafik 10. Grafik hasil evaluasi perkuliahan spesialisasi cabang olahraga
Mata kuliah bulu tangkis merupakan mata kuliah teori dan praktek di lapangan. Mata kuliah ini merupakan matakuliah wajib. Dari 16 angket rentang nilai 1 sampai 5 jika dipersentasekan jumlah jawaban yang memberi jawaban baik $65 \%$ dan baik sekali $23 \%$. Jika dipahami secara keseluruhan dapat dikatakan kualitas hasil evaluasi perkuliahan mata kuliah bulu tangkis ini adalah $88 \%$ dengan kualitas baik. Hal ini dapat dilihat lebih jelas dengan memperhatikan tabel sebagai berikut:

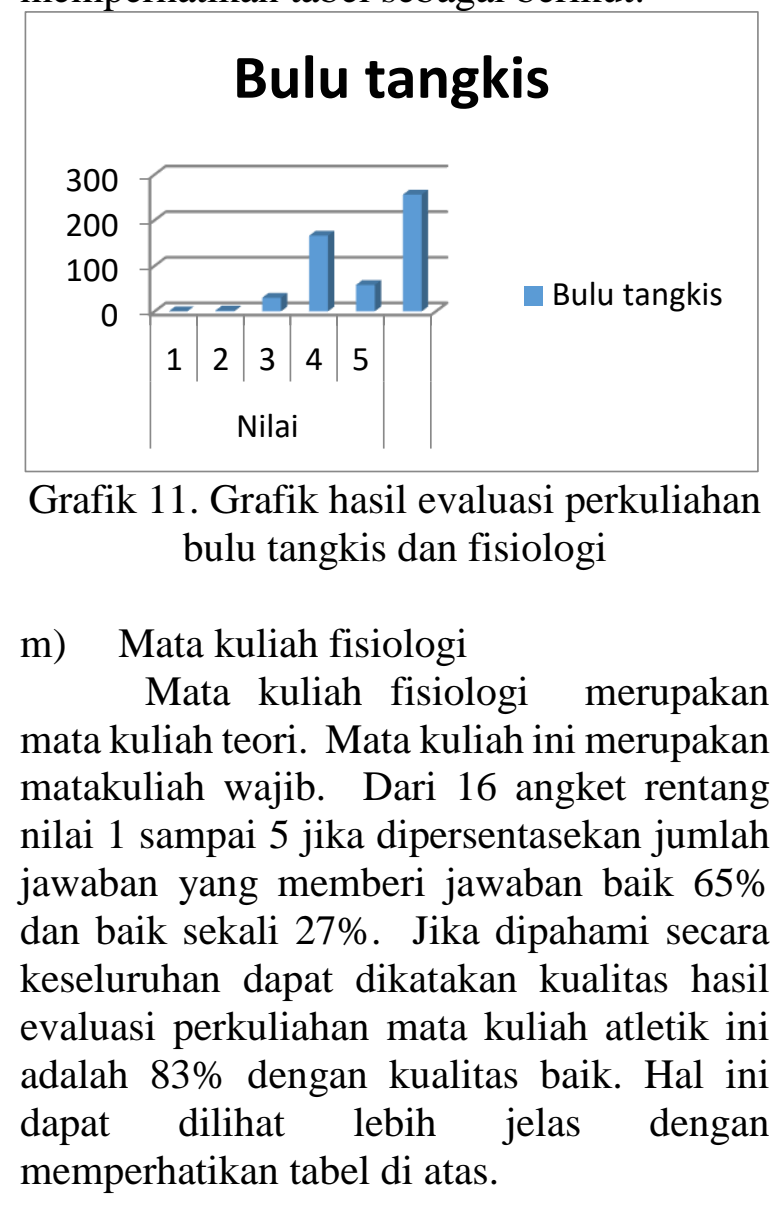

1) Mata kuliah bulu tangkis 


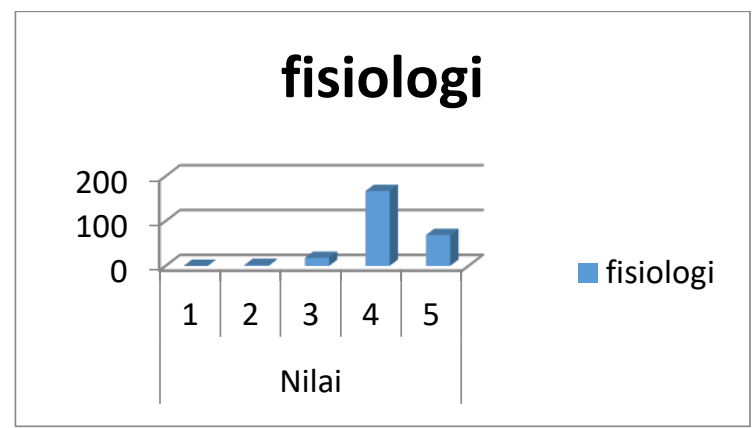

Grafik 12. Grafik hasil evaluasi perkuliahan fisiologi

n) Mata kuliah sosiologi olahraga Mata kuliah psikologi pendidikan merupakan mata kuliah teori. Mata kuliah ini merupakan matakuliah wajib. Dari 16 angket rentang nilai 1 sampai 5 jika dipersentasekan jumlah jawaban yang memberi jawaban baik $59 \%$ dan baik sekali 20\%. Jika dipahami secara keseluruhan dapat dikatakan kualitas hasil evaluasi perkuliahan mata kuliah sosiologi olahraga ini adalah $79 \%$ dengan kualitas baik. Hal ini dapat dilihat lebih jelas dengan memperhatikan tabel sebagai berikut:

\section{sosiologi olahraga}

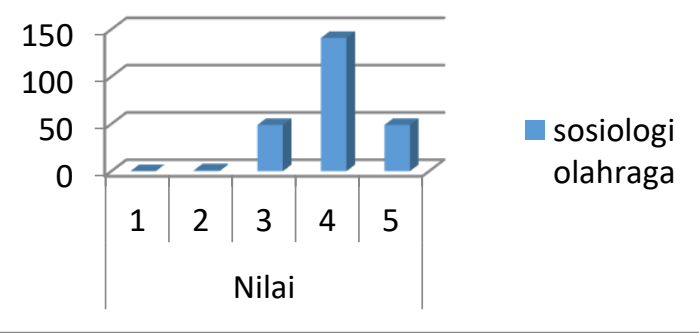

Grafik 13. Grafik hasil evaluasi perkuliahan sosiologi olahraga dan perenc. Program Lat

o) Mata kuliah perenc. Program Lat

Mata kuliah psikologi pendidikan merupakan mata kuliah teori. Mata kuliah ini merupakan matakuliah wajib. Dari 16 angket rentang nilai 1 sampai 5 jika dipersentasekan jumlah jawaban yang memberi jawaban baik $68 \%$ dan baik sekali 24\%. Jika dipahami secara keseluruhan dapat dikatakan kualitas hasil evaluasi perkuliahan mata kuliah perenc. Program Lat ini adalah 92\% dengan kualitas baik. Hal ini dapat dilihat lebih jelas dengan memperhatikan tabel di atas.

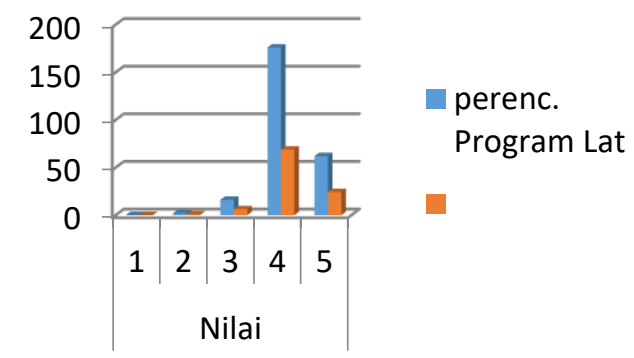

Grafik 14. Grafik hasil evaluasi perkuliahan perenc. Program Lat

p) Mata kuliah Statistika

Mata kuliah Statistika merupakan mata kuliah teori. Mata kuliah ini merupakan matakuliah wajib. Dari 16 angket rentang nilai 1 sampai 5 jika dipersentasekan jumlah jawaban yang memberi jawaban baik $65 \%$ dan baik sekali 19\%. Jika dipahami secara keseluruhan dapat dikatakan kualitas hasil evaluasi perkuliahan mata kuliah Statistika ini adalah $84 \%$ dengan kualitas baik. Hal ini dapat dilihat lebih jelas dengan memperhatikan tabel sebagai berikut:

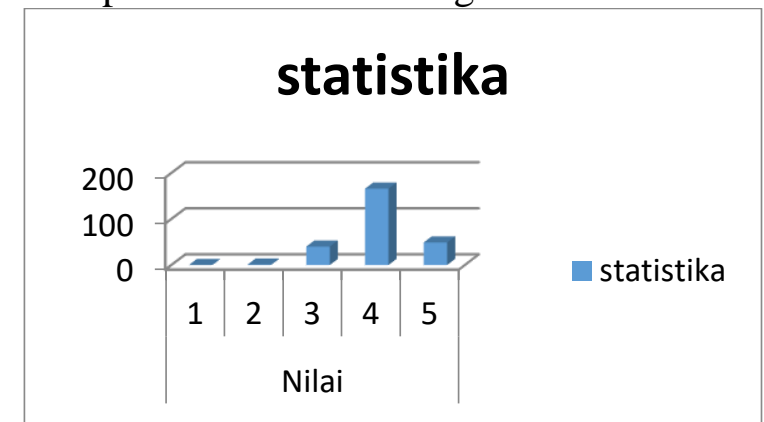

Grafik 15. Grafik hasil evaluasi perkuliahan statistika

q) Mata kuliah ppc

Mata kuliah ppc merupakan mata kuliah teori dan praktek di lapangan. Mata kuliah ini merupakan matakuliah wajib. Dari 16 angket rentang nilai 1 sampai 5 jika dipersentasekan jumlah jawaban yang memberi jawaban baik 59\% dan baik sekali 29\%. Jika dipahami secara keseluruhan 
dapat dikatakan kualitas hasil evaluasi perkuliahan mata kuliah ppc ini adalah $88 \%$ dengan kualitas baik. Hal ini dapat dilihat lebih jelas dengan memperhatikan tabel sebagai berikut:

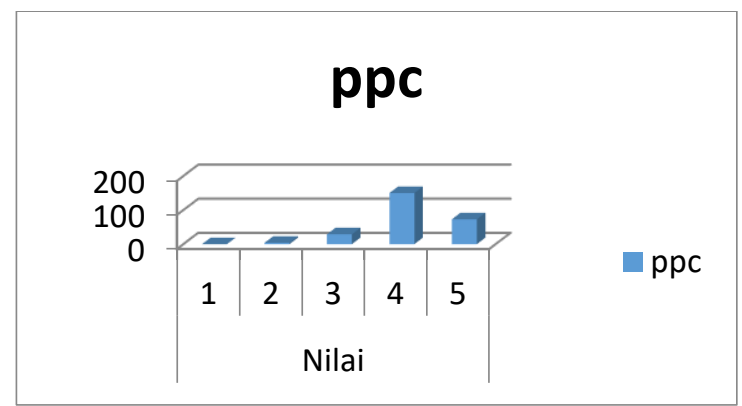

Grafik 16. Grafik hasil evaluasi perkuliahan ppc

r) Mata kuliah pengukuran evaluasi

Mata kuliah pengukuran evaluasi merupakan mata kuliah teori dan praktek di lapangan. Mata kuliah ini merupakan matakuliah wajib. Dari 16 angket rentang nilai 1 sampai 5 jika dipersentasekan jumlah jawaban yang memberi jawaban baik $71 \%$ dan baik sekali $13 \%$. Jika dipahami secara keseluruhan dapat dikatakan kualitas hasil evaluasi perkuliahan mata kuliah pengukuran evaluasi ini adalah $84 \%$ dengan kualitas baik. Hal ini dapat dilihat lebih jelas dengan memperhatikan tabel sebagai berikut:

\section{Pengukuran evaluasi}

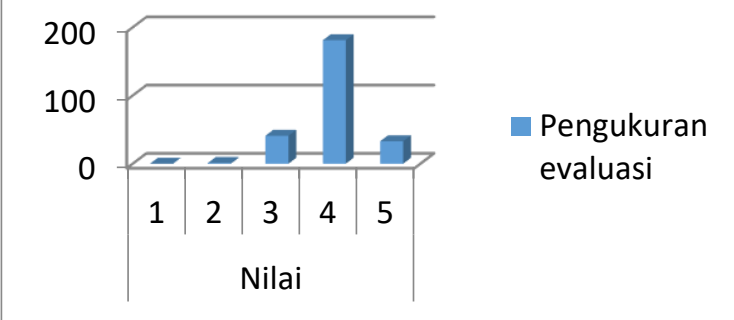

Grafik 17. Grafik hasil evaluasi perkuliahan pengukuran evaluasi

2. Pembahasan.

Berdasarkan pemaparan data diatas rerata persentase rerata lebih di dominasi oleh nilai kurang sekali antara 0 sampai $0.01 \%$, kurang antara 0 sampai $1 \%$, cukup antara 6-24\%, baik antara 48-70\% ,sedangkan nilai sangat baik antara 12 Sampai 36\%. Jika dilihat persentase tersebut dapat dinilai bahwa hasil evaluasi perkuliahan ini sudah baik.

Berdasarkan hasil penelitian ini dapat disimpulkan bahwa menurut pendapat mahasiswa sebagai pemakai proses perkuliahan berpendapat proses perkuliahan yang telah dijalankan diatas $80 \%$ selama satu semester yaitu semester II dan IV dalam kualitas baik. Baik dalam artian diambil secara rerata persentase diatas $80 \%$. Meskipun ada kisaran antara 0 Sampai $1 \%$ penilaian terhadap proses adalah kurang, hal ini lebih banyak pada peralatan sarana dan prasarana sebagai pendukung perkuliahan. Diakui bahwa persedian sarana perkuliahan sudah ada tetapi masih perlu mendapatkan perbaikan atau pengadaan yang baru. Beberapa fasiltas masih dalam status meminjam pihak luar, seperti kolam renang, pemakaian lapangan tenis yang kurang, fasilitas ruang massage yang terlalu sempit 
serta lapangan yang selalu becek ketika hujan.

Pun demikian secara keseluruhan berdasarkan pemaparan data diatas yang diperoleh dari pendapat mahasiswa menyatakan bahwa perkuliahan berjalan dengan baik. Hasil penelitian ini memberika gambaran bahwa dosen telah dapat melaksanakan tugas mengajar. berdasarkan daftar angket tersedia kolom saran. Hampir semua mahasiswa yang bersedia memberikan saran menyarankan untuk memperbaiki fasilitas yang ada.

Berdasarkan bukti penelitian ini iklim suasana akademik perlu dijaga sehingga perkuliahan dapat berjalan sesuai dengan yang direncanakan. Bukti penelitian ini memberikan gambaran bahwa prodi baru (penididikan kepelatihan olahraga) ini telah mampu menyelenggarakan proses belajar mengajar dengan baik. Kelemahan sarana dan prasana menjadi pekerjaan rumah yang harus diperhatikan

\section{KESIMPULAN}

Berdasarkan pemaparan dan analisa data dalam penelitian ini dapat disimpulkan bahwa hasil evaluasi perkuliahan pada semester ini adalah diatas baik dengan angka persentase diatas $80 \%$. Angka ini diestimasi dari penggabungan dari status nilai baik dan baik sekali. Dengan demikian bukti penelitian ini memberikan gambaran bahwa proses perkuliahan telah berlangsung dengan baik. Kelemahan sarana dan prasarana menjadi masukan yang sangat vital yang harus diperhatikan oleh pemangku kebijakan.
Ditjen Dikti. (2008). Sistem Penjaminan Mutu Perguruan Tinggi. Jakarta: Depdiknas.

Hergenhahn, B.R., Matthew W. Olson. (2008). Theories of Learning. Alih bahasa: Tri Wibowo B.S.. Jakarta: Penerbit Prenada Media Group

Imam Barnadib. (1988). Ke Arah Perspektif

Baru Pendidikan. Jakarta: Ditjen Dikti, Depdikbud.

\section{DAFTAR PUSTAKA}

